\title{
ANALISIS RIWAYAT WAKTU GEMPA SESAR PADA SISTEM FONDASI TIANG
}

\author{
Alfandy Firmando ${ }^{1}$, Hendy Wijaya ${ }^{2}$, dan Amelia Yuwono ${ }^{3}$ \\ ${ }^{1}$ Program Studi Sarjana Teknik Sipil, Universitas Tarumanagara, Jl. Letjen S. Parman No.1 Jakarta \\ alfandy.325170092@stu.untar.ac.id \\ ${ }^{2}$ Program Studi Sarjana Teknik Sipil, Universitas Tarumanagara, Jl. Letjen S. Parman No.1 Jakarta \\ rm.hendy@yahoo.com \\ ${ }^{3}$ Program Studi Sarjana Teknik Sipil, Universitas Tarumanagara, Jl. Letjen S. Parman No.1 Jakarta \\ yuwonoamelia@gmail.com
}

Masuk: 10-01-2021, revisi: 01-02-2021, diterima untuk diterbitkan: 11-02-2021

\begin{abstract}
In Indonesia, many active faults that can cause earthquakes, one of them is the Palu Koro fault which extends approximately $240 \mathrm{~km}$ from the north (Palu City) to the south (Malili) to the Gulf of Bone. The effect of this earthquake fault caused enormous damage to infrastructure. The lower structure, namely the foundation, is part of a structure that transmits the load received from axial and lateral forces which then continues into the ground below. This foundation plays a big role in making the structure stand firm; however, pile failures still often occur in Indonesia. Because of that in this journal will be analyzing of the time history of earthquake faults in the pile foundation system. This analysis requires the assistance of a geotechnical based program. The program can process the data provided so that it produces a result that can be analyzed. The results can be in the form of internal forces, and displacement. The result of this curve we can see the effect of the earthquake fault on the foundation. From these results, it is expected to provide data to help plan structures to be built in areas prone to earthquake faults.
\end{abstract}

Keywords: foundation; faults; lateral

\begin{abstract}
ABSTRAK
Wilayah Indonesia banyak terdapat sesar aktif yang dapat menimbulkan gempa salah satunya sesar aktif di Sulawesi adalah sesar Palu Koro yang memanjang kurang lebih $240 \mathrm{~km}$ dari utara (Kota Palu) ke selatan (Malili) hingga Teluk Bone. Pengaruh gempa sesar ini menimbulkan kerusakan yang sangat besar dalam infrastruktur. Struktur bawah yakni Fondasi ialah bagian dari suatu struktur yang meneruskan beban yang diterima dari gaya aksial dan lateral yang kemudian meneruskan ke dalam tanah di bawahnya. Fondasi inilah berperan besar membuat struktur tersebut dapat berdiri kukuh akan tetapi kegagalan tiang masih sering terjadi di Indonesia. Dengan demikian pada jurnal ini dilakukan analisis riwayat waktu gempa sesar pada sistem fondasi tiang. Analisis ini membutuhkan bantuan program berbasis geoteknik. Program dapat mengolah data-data yang diberikan sehingga menghasilkan suatu hasil yang dapat di analisis. Hasil tersebut dapat berupa kurva gaya dalam dan perpindahan. Hasil dari kurva ini kita dapat melihat pengaruh dari gempa sesar tersebut terhadap fondasi. Dari hasil tersebut diharapkan dapat memberikan data-data untuk membantu merencanakan bangunan struktur yang akan dibangun di wilayah yang rawan akan gempa sesar.
\end{abstract}

Kata kunci: fondasi; gempa sesar; lateral

\section{PENDAHULUAN}

Fondasi adalah struktur bagian bawah yang mampu menahan beban gaya lateral dan gaya aksial akibat dari struktur atas yakni bangunan. Fondasi meneruskan beban struktur bangunan tersebut ke lapisan tanah yang berada di bagian bawah tersebut. Beban lateral dapat diakibatkan karena adanya gempa, angin, dan gelombang air laut, oleh karena itu analisis dan desain terhadap beban lateral harus di perhitungkan agar tiang pancang itu sendiri dapat berfungsi dengan baik (Cho dkk, 2020). Perancangan konstruksi struktur bawah tidak hanya memikirkan beban statis melainkan beban dinamik juga hal tersebut dapat dilihat bahwa fondasi dapat mengalami translasi lateral yang cukup parah sehingga menyebabkan hilangnya kapasitas dukung untuk struktur atas dan kegagalan struktur pada tiang. Dengan demikian, tuntutan untuk menahan beban dan deformasi selama gempa bumi mungkin akan menjadi yang paling parah dalam masa desainnya (Castelli dan Maugeri, 2009). 
Tiang

Di Indonesia terdapat salah satu sesar aktif di Sulawesi adalah sesar Palu Koro yang memanjang kurang lebih $240 \mathrm{~km}$ dari utara (Kota Palu) ke selatan (Malili) hingga Teluk Bone. Sesar Palu Koro berhubungan dengan Sesar MatanoSorong dan Lawanoppo-Kendari, sedangkan di ujung utara melalui selat Makasar berpotongan dengan zona subduksi lempeng Laut Sulawesi (Kaharuddin dkk: 2011). Pada umumnya potensi kerusakan akibat gempa bumi yang bersumber dari sesar aktif menimbulkan kerugian dan kerusakan lebih parah dibandingkan gempa bumi yang bersumber di lautan pada skala magnitudo yang sama. Contohnya adalah gempa bumi di Bantul (Yogyakarta) dengan magnitudo $6.3 \mathrm{M}$ pada tahun 2006 akibat aktivitas sesar aktif (Sesar Opak). Gempa bumi ini menimbulkan kerusakan bangunan dan menelan ribuan korban jiwa (Pakpahan dkk, 2015).

Berdasarkan hal tersebut perlu dilakukan analisis sistem fondasi terhadap gempa sesar untuk mengetahui dampak fondasi akibat gempa tersebut dengan menggunakan program berbasis geoteknik.

\section{Parameter Tiang}

Daya dukung ujung tiang pancang dihitung dengan menggunakan formula (Decourt, 1995) adalah sebagai berikut:

$$
Q p=K \mathrm{~b} \bar{N} b(\mathrm{kPa})
$$

Dimana Kb adalah Base Factor (Decourt, 1995) dapat dilihat di Tabel 1.

Tabel 1 Base Factor

\begin{tabular}{ccc}
\hline Soil type & Displacement & Non-Displacement Piles \\
\hline Sand & 325 & 165 \\
Sandy Silt & 205 & 115 \\
Clayey Silt & 165 & 100 \\
Clay & 100 & 80 \\
\hline \multicolumn{3}{c}{ (Sumber: Decourt, 1995) }
\end{tabular}

Nilai $\left(\bar{N}_{b}\right)$ merupakan nilai N-SPT rata-rata disekitar ujung tiang dimana diambil nilai rata-rata N-SPT 8 x diameter diatas ujung tiang dan $2 \mathrm{x}$ diameter dibawah tiang dapat dilihat Gambar 1.

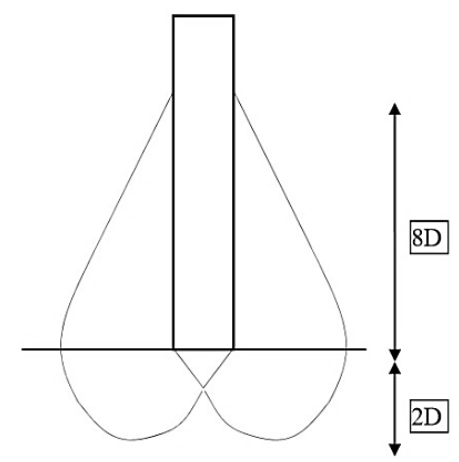

Gambar 1. Bearing Failure Line (Sumber: Decourt,1995)

Daya dukung selimut tiang diperhitungkan dengan persamaan (Decourt, 1995) dengan formula sebagai berikut:

$$
Q \mathrm{~s}=\alpha\left(2.8 N_{60}+10\right)(k P a)
$$

dengan $\alpha=1$ untuk displacement piles untuk kebanyakan tanah dan untuk tiang bor pada tanah lempung, dan 0.5-0.6 untuk tiang bor pada tanah berbutir kasar, $\mathrm{N}_{60}=$ Nilai SPT rata-rata yang dinormalisir terhadap efisiensi $60 \%$ energi sepanjang selimut tiang. Nilai tahanan selimut maksimum dibatasi hingga $250 \mathrm{kPa}$

Daya dukung lateral menggunakan persamaan yang diajukan oleh (Matlock, 1970) untuk jenis tanah lempung lunak dengan kondisi air bebas adalah sebagai berikut:

$$
\begin{gathered}
P u=\left(3+\frac{\gamma^{\prime}{ }_{a v g}}{C u} z+\frac{J}{D} z\right) C u D \\
P u=9 C u D \\
y 50=2.5 \varepsilon 50 D
\end{gathered}
$$




$$
\begin{aligned}
& P=\frac{P u}{2}\left(\frac{y}{y_{50}}\right)^{\frac{1}{3}} \\
& y=8 y_{50}
\end{aligned}
$$

dengan $\mathrm{z}=$ kedalaman tanah $(\mathrm{m}), \mathrm{D}=$ diameter tiang $(\mathrm{m}), \mathrm{Cu}=$ Undrained Shear Strength $(\mathrm{kN} / \mathrm{m}), \gamma_{\text {avg }}^{\prime}=$ tegangan efektif tanah rata-rata $(\mathrm{kN} / \mathrm{m}), \mathrm{J}: 0.25-0.5, \mathrm{y}=$ lendutan $(\mathrm{m})$. Untuk nilai $\varepsilon 50$ dapat dilihat di Tabel 2. P-y curve soft clay dapat dilihat pada Gambar 2 dan P-y curve stiff clay without free water dapat dilihat pada Gambar 3.

Tabel 2. Nilai $\varepsilon 50$ untuk tanah soft dan stiff clay

\begin{tabular}{cc}
\hline Konsistensi Clay & $\mathbf{\varepsilon 5 0}$ \\
\hline Soft & 0.02 \\
Medium & 0.01 \\
Stiff & 0.005 \\
\hline
\end{tabular}

(Sumber: ManualLpile, 2018)

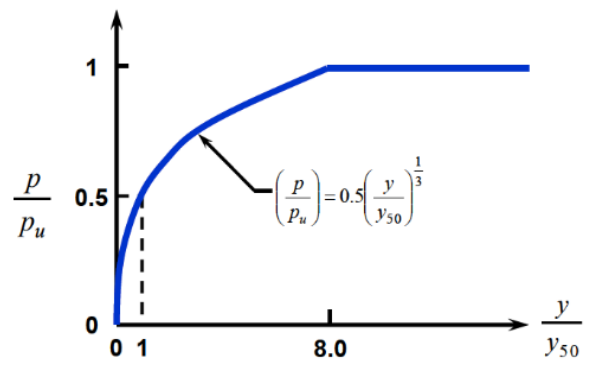

Gambar 2. P-y curve soft clay (Sumber: ManualLpile, 2018)

(Reese dan Welch, 1975) mengajukan bentuk p-y curve untuk tanah lempung kaku pada kondisi di atas muka air tanah. Persamaan Pu nya tetap menggunakan persamaan 3 dan 4. Persamaan yang lain sebagai berikut :

$$
\begin{aligned}
& P=\frac{P u}{2}\left(\frac{y}{y_{50}}\right)^{\frac{1}{4}} \\
& y=16 y_{50}
\end{aligned}
$$

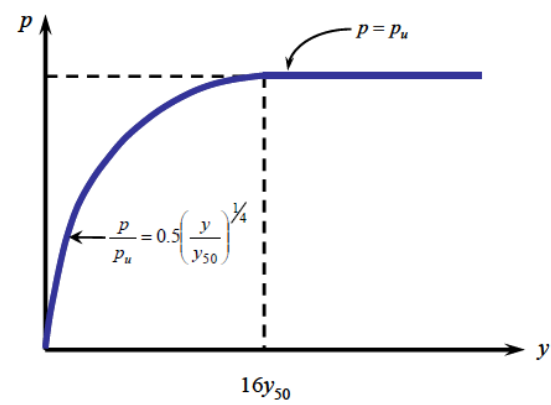

Gambar 3. P-y curve stiff clay without free water (Sumber: ManualL pile, 2018)

Daya dukung lateral untuk non kohesif menggunakan persamaan (Broms, 1964b) mengasumsikan bahwa daya dukung lateral sama dengan 3 kali rankine passive earth pressure.

$$
\begin{aligned}
& P u=3 D \gamma z K p \\
& K p=\tan ^{2}\left(45+\frac{\emptyset \prime}{2}\right)
\end{aligned}
$$

dengan $\mathrm{z}=$ kedalaman tanah $(\mathrm{m}), \mathrm{D}=$ diameter tiang $(\mathrm{m}), \gamma^{\prime}=$ tegangan efektif tanah $(\mathrm{kN} / \mathrm{m}), \emptyset^{\prime}=$ sudut Geser pada kondisi tegangan efektif $\left(^{\circ}\right)$ 


\section{Parameter Tanah}

Parameter tanah yang diperlukan pada program berbasis geoteknik dapat dilihat di tabel 3.

Tabel 3. Parameter program berbasis geoteknik

\begin{tabular}{|c|c|}
\hline Parameter & Deskripsi \\
\hline$\emptyset^{\prime}$ & Sudut geser pada kondisi tegangan efektif \\
\hline c' & Kohesi tanah pada kondisi tegangan efektif \\
\hline$\psi$ & Sudut dilatansi \\
\hline $\mathrm{E}_{50}$ & Garis potong dalam modulus kekakuan dalam uji triaxial \\
\hline $\mathrm{E}_{\mathrm{ur} \text {; ref }}$ & Kekakuan tidak berbeban \\
\hline $\mathrm{E}_{\text {oed; ref }}$ & Modulus kekakuan tangen untuk pembebanan oedometer primer \\
\hline $\mathrm{V}_{\mathrm{ur}}$ & Poisson rasio \\
\hline $\mathrm{m}$ & kekuatan untuk kekakuan ketergantungan tingkat stres \\
\hline $\mathrm{R}_{\mathrm{f}}$ & Rasio kegagalan $(0,9)$ \\
\hline $\mathrm{P}_{\mathrm{ref}}$ & Referensi tegangan untuk kekakuan $\left(100 \mathrm{kN} / \mathrm{m}^{2}\right)$ \\
\hline $\mathrm{K}_{0 ; \mathrm{nc}}$ & Nilai untuk konsolidasi normal tanah $\left(\right.$ Ko $\left.=1-\sin \left(\phi^{\prime}\right)\right)$ \\
\hline $\mathrm{G}_{0}^{\mathrm{ref}}$ & Referensi modulus geser pada regangan yang sangat kecil $\left(\varepsilon<10^{-6}\right)$ \\
\hline$\gamma_{0.7}$ & Regangan geser $\left(\mathrm{Gs}=0,72 \mathrm{G}_{0)}\right)$ \\
\hline
\end{tabular}

Korelasi $\mathrm{E}_{50}$ didapatkan dari hasil uji laboratorium yang sudah dilakukan. Korelasi antara N-SPT dan $\mathrm{G}_{0}^{\text {ref }}$ untuk tanah kohesif dikenalkan oleh (Imai dan Tonouchi, 1982) sebagai berikut:

$$
G_{0}=15.56\left(N_{60}\right)^{0.68}(\mathrm{MPa})
$$

Korelasi antara N-SPT dan $\mathrm{G}_{0}^{\text {ref }}$ untuk tanah granular dikenalkan oleh (Imai dan Tonouchi :1982) sebagai berikut:

$$
G_{0}=15600\left(N_{60}\right)^{0.68}(\mathrm{kPa})
$$

Korelasi $\gamma_{0.7}$ untuk tanah kohesif dapat dicari dari laporan eksperimen data (Vucetic dan Dobry: 1991) dengan menggunakan hubungan antara $\gamma_{0.7}$ dan plasticity index. Berdasarkan data tersebut $\gamma_{0.7}$ dapat di perkirakan dengan korelasi empiris berikut ini:

$$
\begin{aligned}
& \gamma_{0.7}=\gamma_{0.7}^{r e f}+5 \cdot 10^{-6} P I \text { Untuk PI }<15 \\
& \gamma_{0.7}=10^{1.15} \log (P I)-5.1 \text { Untuk PI } \geq 15
\end{aligned}
$$

dengan $\gamma_{0.7}^{\text {ref }}(\mathrm{PI}=0)=1 \cdot 10^{-4}, \mathrm{PI}=$ Plasticity index

Korelasi $\gamma_{0.7}$ untuk tanah granular dari (Darendeli dan Stokoe: 2001) dengan menggunakan rumus:

$$
\gamma_{0.7}=\gamma_{0.7}^{r e f}\left(\frac{p^{\prime}}{P_{a}}\right)^{0.35}
$$

dengan $\mathrm{Pa}=100(\mathrm{kPa}), \gamma_{0.7}^{\mathrm{ref}}(\mathrm{Pa})=1.26 \cdot 10^{-4}, \mathrm{p}^{\prime}=$ mean effective stress $(\mathrm{kPa})$

\section{Parameter damping}

(Hashash dan Park: 2002) menyarankan bahwa pemilihan target frekuensi pertama adalah frekuensi tanah $\left(\mathrm{f}_{1}\right)$, target frekuensi kedua $\left(f_{2}\right)$ adalah kelipatan ganjil pertama terdekat yang lebih besar dari $f_{2} / f_{p}$. $f_{p}$ adalah frekuensi pergerakan gempa yang dapat ditentukan dari Fourier Spectrum. Frekuensi natural dari tanah (f1) dapat ditentukan dengan rumus:

$$
f_{1}=\frac{V s}{4 z}
$$

dengan Vs = kecepatan rambat gelombang geser $(\mathrm{m} / \mathrm{s}), \mathrm{z}=$ kedalaman tanah $(\mathrm{m})$

\section{METODE PENELITIAN}

Pada penelitian ini yang dilakukan pertama kali yaitu pengumpulan data. Data tanah yang berasal dari berbagai lokasi. Data tanah berupa laporan uji laboratorium dan boring log. Data tanah yang digunakan adalah tanah SC (tanah keras), SD (tanah sedang), SE (tanah lunak). Data tanah tersebut akan dimodelkan dalam homogen atau satu lapisan di dalam program. Data-data dilakukan korelasi mengikuti sumber referensi teori yang bisa dari jurnal, buku, dan dokumen yang 
berkaitan untuk mendapatkan parameter yang dibutuhkan program. Spesifikasi tiang pancang menggunakan brosur JHS. Korelasi parameter tanah yang digunakan pada penelitian ini dapat dilihat di Tabel 4. Parameter tiang yang digunakan dapat dilihat di Tabel 5. Daya dukung selimut dan ujung tiang menggunakan persamaan Decourt yang dapat dilihat di Tabel 6. Daya dukung lateral yang dipakai menggunakan p-y curve dengan bantuan Lpile untuk tanah lunak dan sedang, sedangkan tanah keras menggunakan persamaan Broms yang dapat dilihat di Tabel 7 dan Gambar 4. Riwayat waktu gempa sesar yang dipakai mengikuti ASCE 7:16 dan SNI 1726:2019 11.2.2 yakni minimal menggunakan 11 riwayat waktu. Parameter tiang, tanah, dan beban dimasukkan ke dalam program. Pengelolaan data yang dilakukan menggunakan program berbasis geoteknik elemen hingga. Program akan melakukan analisis tiang tersebut hingga menghasilkan hasil berupa gaya dalam dan displacement. Hasil analisis tersebut akan dibandigkan berdasarkan konsistensi tanah.

Tabel 4. Korelasi parameter tanah

\begin{tabular}{cccc}
\hline \multicolumn{4}{c}{ Korelasi Parameter tanah } \\
\hline Konsistensi & Tanah Lunak & Tanah Sedang & Tanah keras \\
Jenis Tanah & Clay & Silty clay & Silty Sand \\
Material Model & Hs small & Hs small & Hs small \\
Drainage Type & Undrained A & Undrained A & Undrained A \\
$\gamma_{\text {sat }}$ & 14,686 & 17,826 & 15,718 \\
$\gamma_{\text {unsat }}$ & 14,686 & 16,360 & 15,696 \\
$\emptyset$ & 23,850 & 25,910 & 29,700 \\
c' & 30,880 & 41,833 & 88,000 \\
$\mathrm{E}_{50}$ & 9150,765 & 12056,651 & 14381,515 \\
Eoed; ref & 9150,765 & 12056,651 & 14381,515 \\
Eur; ref & 27452,295 & 36169,952 & 43144,544 \\
Vur & 0,200 & 0,200 & 0,200 \\
m & 0,500 & 0,500 & 0,500 \\
Rf & 0,900 & 0,900 & 0,900 \\
Pref & 100 & 100 & 100 \\
K0; nc & 0,596 & 0,563 & 0,505 \\
Gref & 36473,3675 & 58435,4321 & 141741,112 \\
$\gamma_{0.7}$ & 0,000529 & 0,0008050 & 0,0001701 \\
\hline
\end{tabular}

Tabel 5. Parameter tiang

\begin{tabular}{cccc}
\hline Parameter & Simbol & Embedded Beam (row) & Satuan \\
\hline Young's Modulus & $\mathrm{E}$ & 30568071,58 & $\mathrm{kN} / \mathrm{m}^{2}$ \\
Unit weight & $\mathrm{Y}$ & 25 & $\mathrm{kN} / \mathrm{m}^{3}$ \\
Predefined Pile Type & - & Massive Square Beam & - \\
Diameter & $\mathrm{D}$ & 0,5 & $\mathrm{~m}$ \\
Luas & $\mathrm{Ab}$ & 0,25 & $\mathrm{~m}^{2}$ \\
Momen inersia & $\mathrm{I}$ & 0,005208333 & $\mathrm{~m}^{4}$ \\
\hline
\end{tabular}

Tabel 6. Daya dukung ujung dan selimut tiang

\begin{tabular}{ccccccc}
\hline $\begin{array}{c}\text { Jenis } \\
\text { Tanah }\end{array}$ & $\begin{array}{c}\text { Tipe } \\
\text { Tanah }\end{array}$ & Dimensi & N-SPT & Kb & $\begin{array}{c}\text { Daya Dukung } \\
\text { Selimut } \\
\text { (kN/m) }\end{array}$ & $\begin{array}{c}\text { Daya } \\
\text { Dukung } \\
\text { Ujung (kN) }\end{array}$ \\
\hline $\begin{array}{c}\text { Tanah } \\
\text { Lunak } \\
\text { Tanah }\end{array}$ & Clay & $0.5 \mathrm{~m} \times 0.5 \mathrm{~m}$ & 3 & 100 & 36,8 & 75 \\
$\begin{array}{c}\text { Sedang } \\
\text { Tanah }\end{array}$ & $\begin{array}{l}\text { Clay } \\
\text { Silty }\end{array}$ & $0.5 \mathrm{mx} 0.5 \mathrm{~m}$ & 6 & 165 & 53,6 & 247,5 \\
Keras & Sand & $0.5 \mathrm{mx} 0.5 \mathrm{~m}$ & 22 & 205 & 143,2 & 1127,5 \\
\hline
\end{tabular}


Tabel 7. Tahanan tanah per satuan panjang

\begin{tabular}{cccc}
\hline \multirow{2}{*}{ Kedalaman $(\mathbf{m})$} & Tanah Lunak & Tanah Sedang & Tanah Keras \\
\cline { 2 - 4 } & P-y curve $(\mathbf{k N} / \mathbf{m})$ & P-y curve $(\mathbf{k N} / \mathbf{m})$ & Broms $(\mathbf{k N} / \mathbf{m})$ \\
\hline 0 & 61,89 & 73,2 & 0 \\
0,5 & 75,876 & 89,856 & 34,941 \\
1 & 89,863 & 106,512 & 69,881 \\
1,5 & 103,849 & 123,168 & 104,822 \\
2 & 117,836 & 139,824 & 139,763 \\
2,5 & 131,822 & 156,48 & 174,703 \\
3 & 145,809 & 173,136 & 209,644 \\
3,5 & 159,795 & 189,792 & 244,585 \\
4 & 173,782 & 206,448 & 279,525 \\
4,5 & 185,67 & 219,6 & 314,466 \\
5 & 185,67 & 219,6 & 349,407 \\
5,5 & 185,67 & 219,6 & 384,348 \\
6 & 185,67 & 219,6 & 419,288 \\
6,5 & 185,67 & 219,6 & 454,229 \\
7 & 185,67 & 219,6 & 489,170 \\
7,5 & 185,67 & 219,6 & 524,110 \\
8 & 185,67 & 219,6 & 559,051 \\
8,5 & 185,67 & 219,6 & 593,992 \\
9 & 185,67 & 219,6 & 628,932 \\
9,5 & 185,67 & 219,6 & 663,873 \\
10 & 185,67 & 219,6 & 698,814 \\
10,5 & 185,67 & 219,6 & 733,754 \\
11 & 185,67 & 219,6 & 768,695 \\
11,5 & 185,67 & 219,6 & 803,636 \\
12 & 185,67 & 219,6 & 838,576 \\
\hline
\end{tabular}
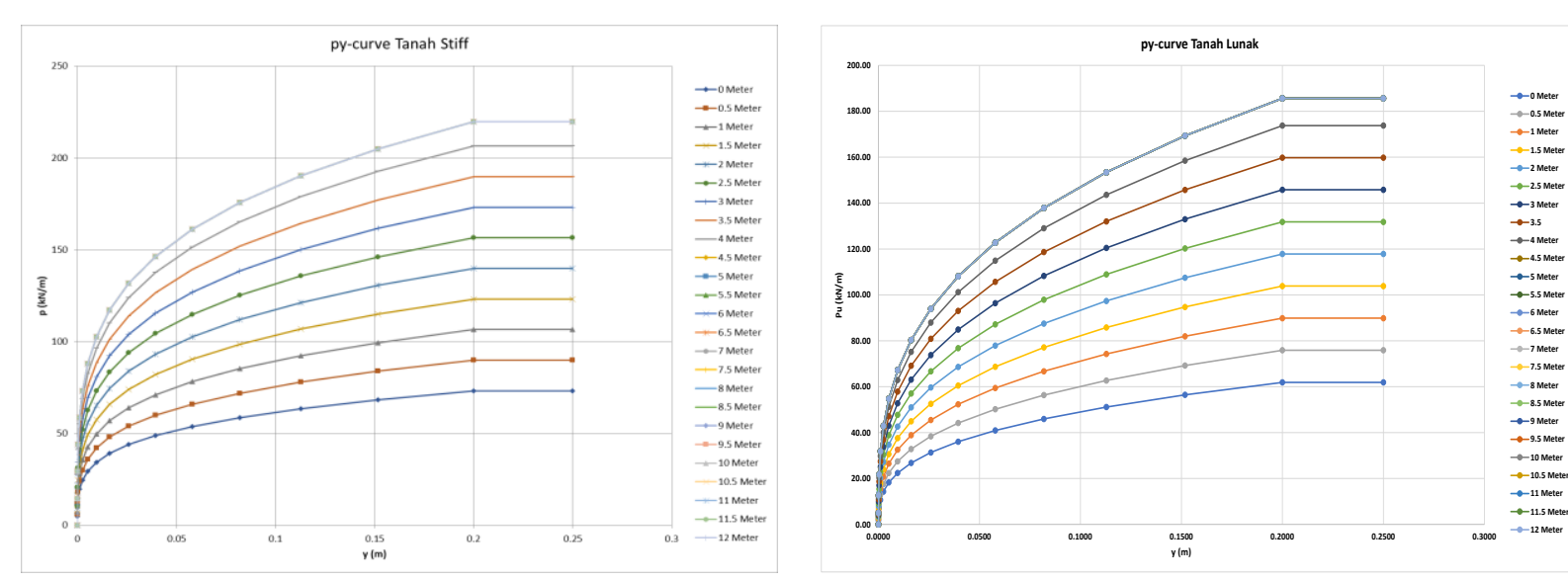

Gambar 4. P-y curve tanah lunak dan sedang

Keterbatasan data riwayat waktu di Indonesia maka digunakan riwayat waktu gempa yang berada di luar Indonesia. Data gempa yang digunakan adalah data gempa riwayat waktu akibat sesar yang berasal dari tabel studi (Lu dan Panagiotou, 2014) ditambah 1 riwayat waktu yang akibat gempa sesar untuk memenuhi syarat SNI 1726:2019 11.2.2. Data gempa yang digunakan yakni gempa yang dekat dengan patahan atau dekat sesar sesuai dengan SNI 1726:2019 6.1.1. Pada tabel 8 dapat dilihat pergerakan tanah dideteksi memiliki jarak dari bidang sesar (Rrup) kurang dari $10 \mathrm{~km}$. Data gempa tersebut di ambil dari website Pacific Earthquake Engineering Research Center (PEER) Ground Motion Database. Data yang dipakai berbentuk akselerasi dapat dilihat di Gambar 5. Parameter rayleigh akan dihitung oleh program dengan memasukkan $\mathrm{f}_{1}$ dan $\mathrm{f}_{2}$ yang dapat dilihat di Tabel 9 dan Tabel 10, sedangkan parameter $\mathrm{f}_{\mathrm{p}}$ dapat dilihat di fourier spectrum pada Gambar 6. Target dari rasio damping adalah $1 \%$ (critically damped). Parameter rayleigh $\alpha$ dan $\beta$ akan dihitung oleh program setelah memasukkan $\mathrm{f}_{1}, \mathrm{f}_{2}$ dan target rasio. 
Tabel 8. Daftar gempa sesar

\begin{tabular}{|c|c|c|c|c|c|c|c|}
\hline No & $\begin{array}{c}\text { Nama gempa, tempat, dan } \\
\text { tahun }\end{array}$ & Mw & Nama stasiun & $\begin{array}{l}\text { Rrup } \\
\text { (km) }\end{array}$ & PGV(m/s) & Tp,1 (s) & Tp,2 (s) \\
\hline 1 & Christchurch, NZ,2011 & 6,3 & PRPC & 2,5 & 1,18 & 2,3 & 4,6 \\
\hline 2 & Northridge, CA,1994 & 6,7 & Sylmar Conv, Stat & 5,4 & 1,3 & 2,6 & 1,2 \\
\hline 3 & Imperial Valley, CA, 1979 & 6,5 & El Centro Array 6 & 1,4 & 1,12 & 3,5 & 7,7 \\
\hline 4 & Kobee, Japan,1995 & 6,9 & Takatori & 1,5 & 1,69 & 1,9 & 1,1 \\
\hline 5 & Loma Prieta, CA,1989 & 6,9 & LGPC & 3,9 & 1,02 & 2,9 & 1,2 \\
\hline 6 & Landers, CA,1992 & 7,3 & Lucerne & 2,2 & 0,93 & 4,8 & 10,5 \\
\hline 7 & Kocaeli, Turkey,1999 & 7,5 & YPT & 4,8 & 0,49 & 7,7 & 3 \\
\hline 8 & Duzce, Turkey,1999 & 7,1 & Duzce & 6,6 & 0,61 & 5,5 & 2,9 \\
\hline 9 & Tabas, Turkey,1978 & 7,4 & Tabas & 2,1 & 1,21 & 4,7 & 3,8 \\
\hline 10 & Chi-Chi, Taiwan,1999 & 7,6 & CHY101 & 9,9 & - & 5,3 & - \\
\hline 11 & Parkfield, CA,2004 & 6 & Cholame 4W & 4,23 & - & - & - \\
\hline
\end{tabular}
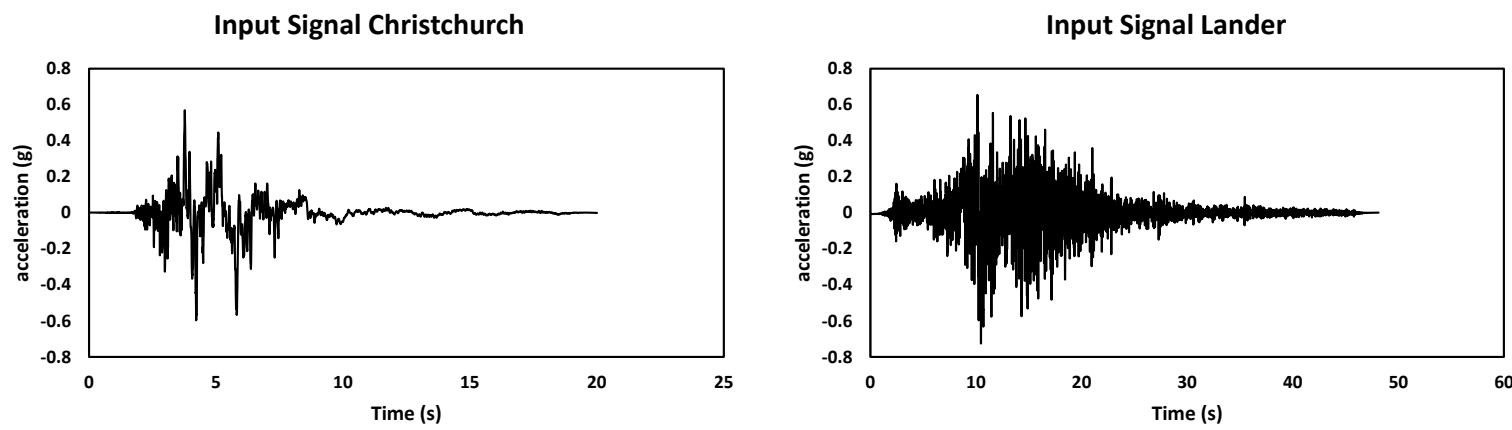

Gambar 5. Input signal gempa dalam bentuk akselerasi

Tabel 9. Perhitungan $\mathrm{f}_{1}$

\begin{tabular}{ccc}
\hline Tanah & Vs $(\mathbf{m} / \mathbf{s})$ & $\mathbf{f}_{\mathbf{1}}$ \\
\hline Tanah Lunak & 175 & 1,458 \\
Tanah Sedang & 250 & 2,083 \\
Tanah Keras & 400 & 3,333 \\
\hline
\end{tabular}

Tabel 10. Perhitungan $\mathrm{f}_{2}$

\begin{tabular}{ccccccccc}
\hline \multirow{2}{*}{ No } & \multirow{2}{*}{ Gempa } & \multirow{2}{*}{$\mathbf{f}_{\mathbf{p}}(\mathbf{H z})$} & \multicolumn{2}{c}{ Tanah Lunak } & \multicolumn{2}{c}{ Tanah Sedang } & \multicolumn{2}{c}{ Tanah Keras } \\
\cline { 6 - 9 } & & $\mathbf{f}_{\mathbf{p}} / \mathbf{f}_{\mathbf{1}}$ & $\mathbf{f}_{\mathbf{2}}$ & $\mathbf{f}_{\mathbf{p}} / \mathbf{f}_{\mathbf{1}}$ & $\mathbf{f}_{\mathbf{2}}$ & $\mathbf{f}_{\mathbf{p}} / \mathbf{f}_{\mathbf{1}}$ & $\mathbf{f}_{\mathbf{2}}$ \\
\hline 1 & Chi-Chi & 0,22 & 0,151 & 1 & 0,1056 & 1 & 0,066 & 1 \\
2 & Christchurch & 0,65 & 0,446 & 1 & 0,312 & 1 & 0,195 & 1 \\
3 & Duzce & 0,77 & 0,528 & 1 & 0,3696 & 1 & 0,231 & 1 \\
4 & Imperial valley & 0,33 & 0,226 & 1 & 0,1584 & 1 & 0,099 & 1 \\
5 & Kobe & 0,83 & 0,569 & 1 & 0,3984 & 1 & 0,249 & 1 \\
6 & Kocaeli & 0,28 & 0,192 & 1 & 0,1344 & 1 & 0,084 & 1 \\
7 & Lander & 9,41 & 6,453 & 7 & 4,5168 & 5 & 2,823 & 3 \\
8 & Lomaprieta & 1,64 & 1,125 & 3 & 0,7872 & 1 & 0,492 & 1 \\
9 & Northridge & 0,86 & 0,590 & 1 & 0,4128 & 1 & 0,258 & 1 \\
10 & Tabas & 1,28 & 0,878 & 1 & 0,6144 & 1 & 0,384 & 1 \\
11 & Parkfield & 2,34 & 1,605 & 3 & 1,1232 & 3 & 0,702 & 1 \\
\hline
\end{tabular}



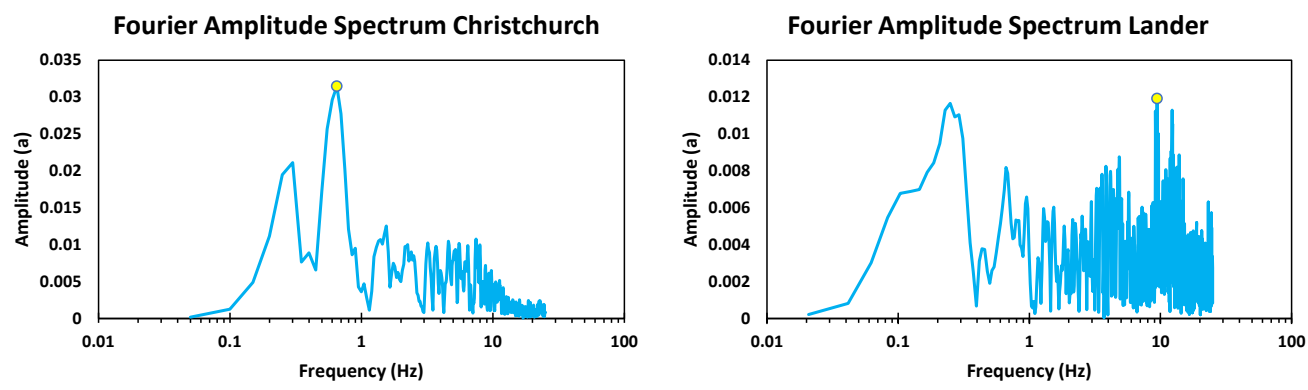

Gambar 6. Fourier amplitude spectrum

Parameter $\mathrm{E}_{50}$ dapat dicari dengan menggunakan hasil uji lab triaxial CU dari spesimen tanah lokasi proyek yang dipakai. Dilakukan plotting $\sigma_{3}$ dengan $\varepsilon$ setiap spesimen maka dapat diketahui $\mathrm{E}_{50}$ saat tegangan referensi $100 \mathrm{kPa}$. Hasil dapat dilihat di Gambar 7 dan Tabel 11.
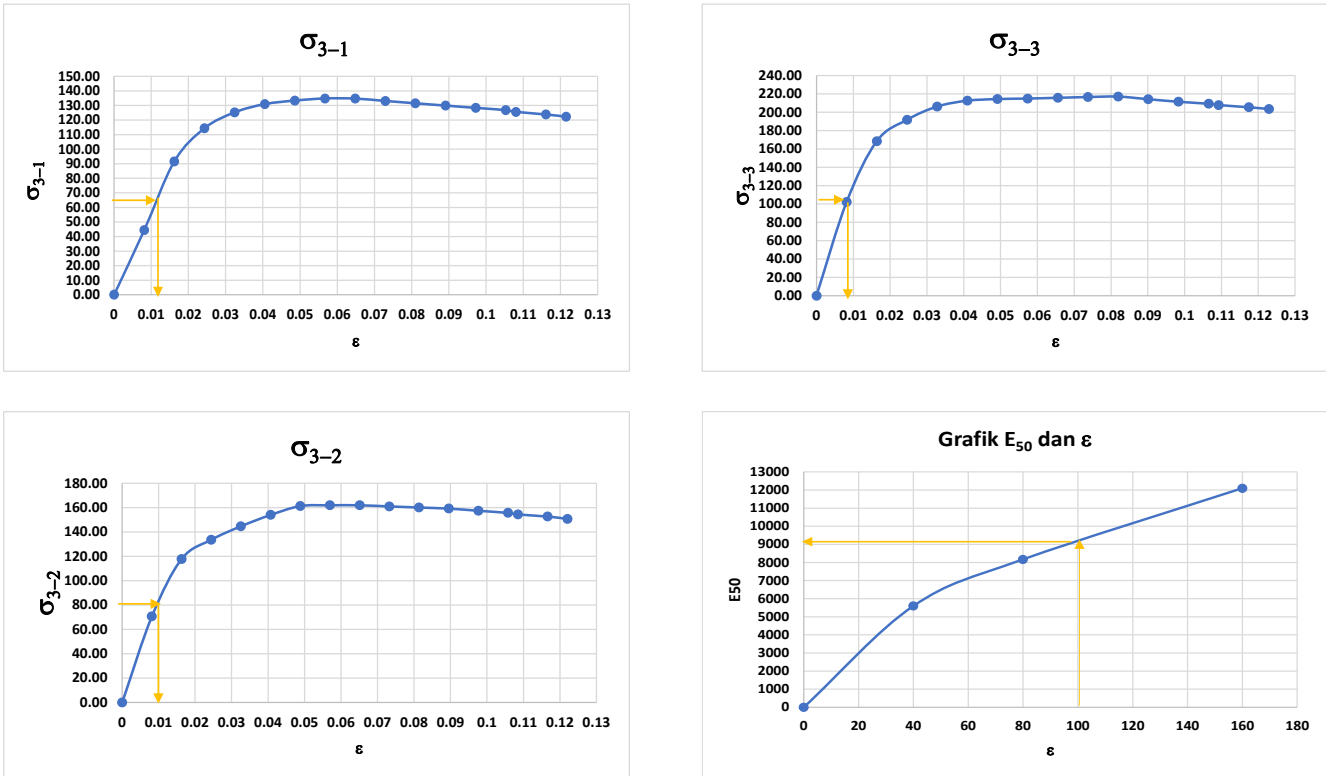

Gambar 7. Grafik korelasi $\mathrm{E}_{50}$ tanah lunak

Tabel 11. Hasil korelasi parameter $\mathrm{E}_{50}$ tanah lunak

\begin{tabular}{ccccccc}
\hline $\boldsymbol{\sigma}$ & $\begin{array}{c}\text { Effective } \\
\text { confining stress }\end{array}$ & $\boldsymbol{\sigma}_{3}($ Max $)$ & $\mathbf{0 . 5} \boldsymbol{\sigma}_{\mathbf{3}}$ & $\boldsymbol{\varepsilon}$ & $\mathbf{E}_{\mathbf{5 0}}$ & $\mathbf{E}_{\mathbf{5 0}}($ Ref 100) \\
\hline$\sigma_{3-1}$ & 40,00 & 134,78 & 67,3887 & 0,012045 & 5594,60 & \\
$\sigma_{3-2}$ & 80,00 & 162,02 & 81,00908 & 0,009917 & 8168,85 & 9150,764 \\
$\sigma_{3-3}$ & 160,00 & 217,20 & 108,5988 & 0,008978 & 12096,51 & \\
\hline
\end{tabular}

\section{Pemodelan tiang}

Pemodelan tiang menggunakan struktur embbeded beam (row). Tiang yang digunakan adalah tiang pancang berbentuk kotak dengan kedalaman $12 \mathrm{~m}$. Pemodelan tanah dilakukan create interface untuk pengurangan kekuatan tanah. Beban gempa di letakkan di atas tiang dalam bentuk line displacement. Komponen $\mathrm{X}$ gempa dimodelkan dalam sebagai line displacement bentuk prescribed dengan uniform value $0.5 \mathrm{~m}$ dan komponen Y dalam bentuk free. Mesh yang digunakan dalam penelitian ini adalah fine untuk sekitar tiang dan medium untuk sisanya. Pemodelan tanah memiliki lebar $40 \mathrm{~m}$ dengan kedalaman $30 \mathrm{~m}$. Muka air tanah di kedalaman $30 \mathrm{~m}$ sehingga tekanan air pori diabaikan. Beban yang ditinjau hanya beban gempa maka dari itu tanah dimodelkan undrained karena beban gempa hanya terjadi seketika. Boundary condition yang digunakan pada model ini adalah viscous untuk Xmin dan Xmax, Boundary condition Ymin digunakan compilant base. Pemodelan tanah, tiang, dan beban gempa yang dipergunakan ditunjukkan dalam Gambar 8. Pemodelan ini terdiri dari fase yang dapat dilihat di tabel 12. 


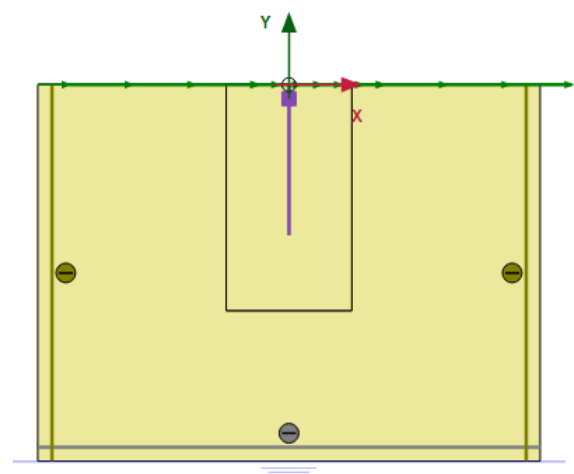

Gambar 8. Pemodelan tiang

Tabel 12. Phase pemodelan program

\begin{tabular}{ccc}
\hline Phase & Calculation type & Deskripsi \\
\hline Initial Phase & K0-Procedure & - \\
Phase-1 & Plastic & Reset Displacements to zero \\
Phase-2 & Dynamic & Semua detik waktu interval gempa \\
Phase-3 & Dynamic & Detik interval dimana akselerasi terbesar \\
\hline
\end{tabular}

\section{HASIL DAN PEMBAHASAN}

\section{Hasil analisis tiang akibat gempa christchurch}

Analisis tiang dengan beban gempa christchurch dimana stage construction phase ke 2 menggunakan waktu interval 20 detik dan phase ke 3 menggunakan waktu interval 4,22 detik. Dari hasil analisis program dapat dilihat bahwa tiang di tanah keras memiliki gaya dalam normal, lintang, dan momen paling besar diikuti tanah sedang dan tanah lunak yang dapat dilihat di Gambar 9, Gambar 10, Gambar 11, dan Tabel 13. Displacement tiang arah X yang terjadi pada tanah lunak, sedang, dan keras memiliki nilai yang sama besar di atas kepala tiang dan displacement arah X untuk bagian tiang yang tertanam pada tanah lunak lebih kecil dari pada tanah sedang dan tanah keras yang dapat dilihat di Gambar 12. Displacement tiang arah Y ke bawah yang terjadi pada tanah keras memiliki nilai paling kecil diikuti tanah sedang, dan tanah lunak yang dapat dilihat di Gambar 13 .

Tabel 13. Hasil analisis tiang akibat gempa christchurch

\begin{tabular}{ccccccc}
\hline $\begin{array}{c}\text { Jenis } \\
\text { Tanah }\end{array}$ & Phase & $\begin{array}{c}\text { Normal } \\
(\mathbf{k N})\end{array}$ & $\begin{array}{c}\text { Lintang } \\
(\mathbf{k N})\end{array}$ & $\begin{array}{c}\text { Momen } \\
(\mathbf{k N m})\end{array}$ & $\begin{array}{c}\text { Displacement X } \\
(\mathbf{m m})\end{array}$ & $\begin{array}{c}\text { Displacement } \mathbf{Y} \\
(\mathbf{m m})\end{array}$ \\
\hline \multirow{2}{*}{ Tanah Lunak } & Phase 2 & 29,354 & 13,790 & 35,092 & 4,620 & 1,336 \\
& Phase 3 & 14,449 & 23,689 & 35,962 & 4,385 & 0,638 \\
\multirow{2}{*}{ Tanah Sedang } & Phase 2 & 32,127 & 20,886 & 47,641 & 5,594 & 0,747 \\
\multirow{2}{*}{ Tanah Keras } & Phase 3 & 16,337 & 29,124 & 38,694 & 4,385 & 0,432 \\
& Phase 2 & 38,746 & 14,607 & 33,238 & 4,974 & 0,361 \\
& Phase 3 & 17,023 & 35,694 & 47,669 & 4,385 & 0,183 \\
\hline
\end{tabular}
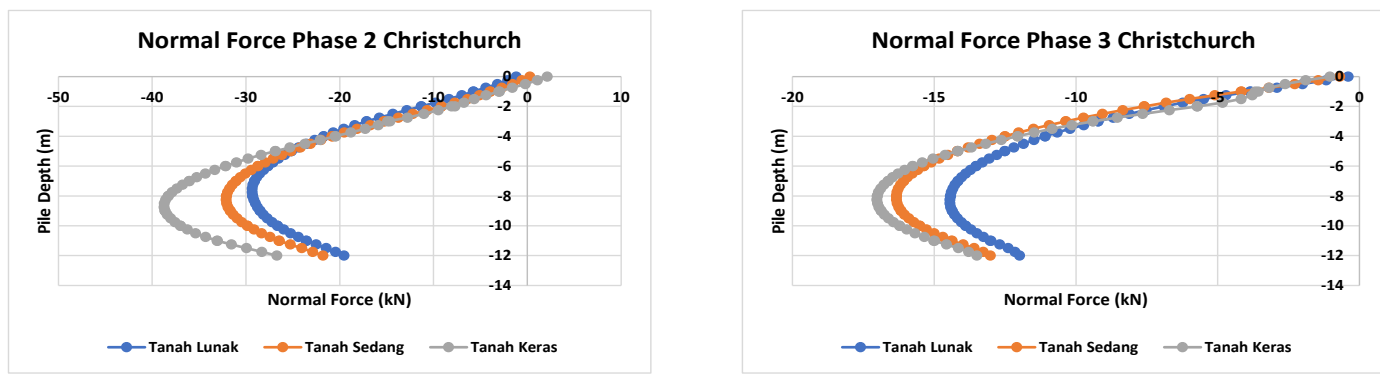

Gambar 9. Normal force tiang akibat gempa christchurch 

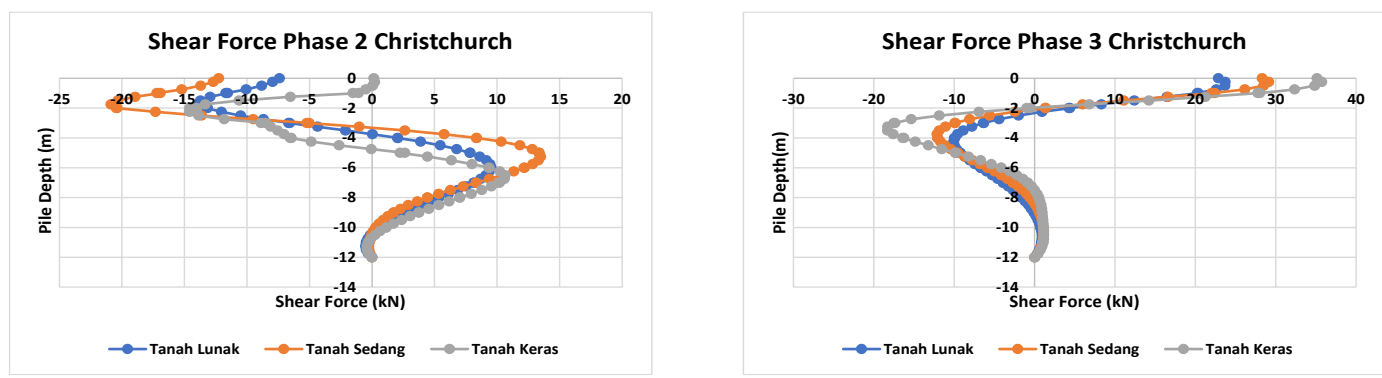

Gambar 10. Shear force tiang akibat gempa christchurch
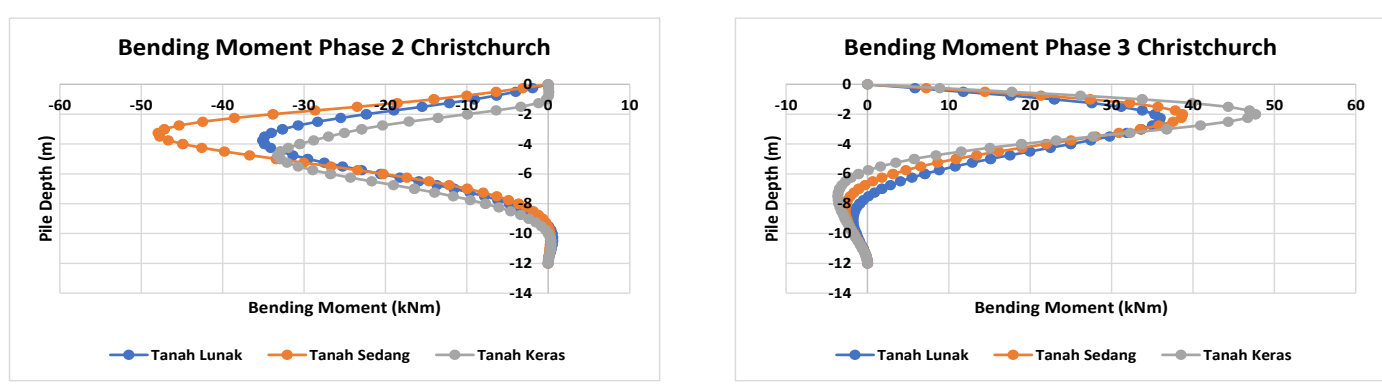

Gambar 11. Bending moment tiang akibat gempa christchurch
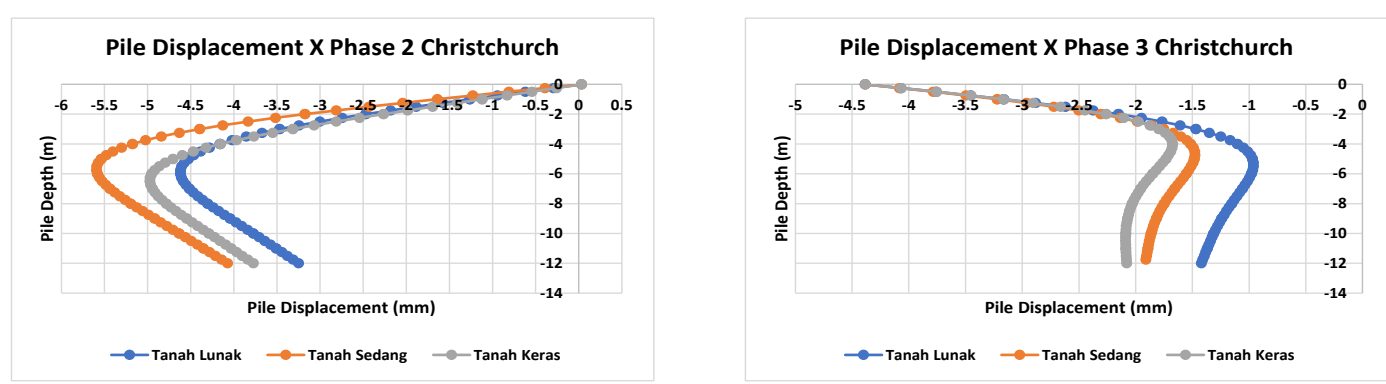

Gambar 12. Displacement tiang arah x akibat gempa christchurch
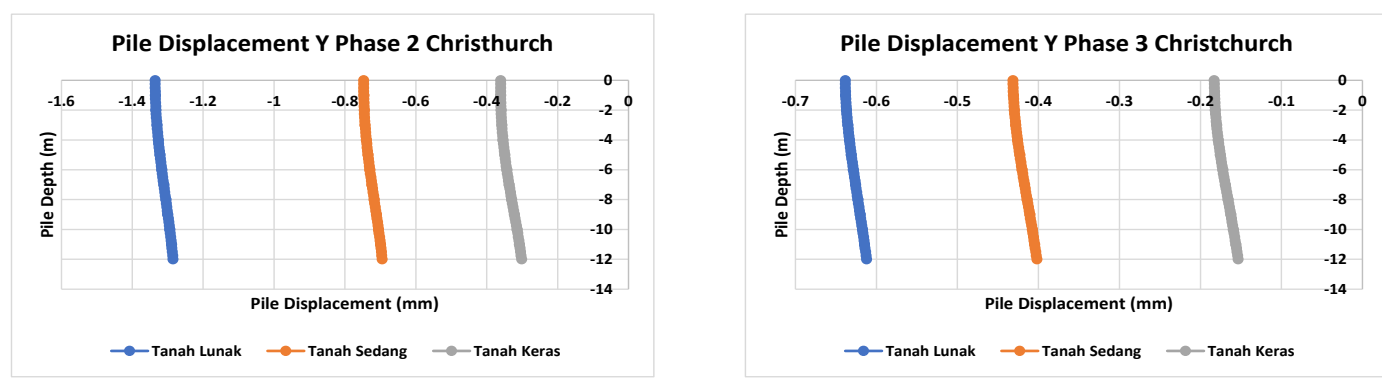

Gambar 13. Displacement tiang arah y akibat gempa christchurch

\section{Hasil analisis tiang akibat gempa lander}

Analisis tiang dengan beban gempa Lander dimana stage construction phase ke 2 menggunakan waktu interval 48,13 detik dan phase ke 3 menggunakan waktu interval 10,48 detik. Dari hasil analisis program dapat dilihat bahwa tiang di tanah sedang memiliki gaya dalam lintang dan momen paling besar diikuti tanah keras dan tanah lunak, sedangkan gaya dalam normal tekan yang terjadi pada tiang di tanah keras memiliki nilai paling besar diikuti tanah sedang dan keras yang dapat dilihat di Gambar 14, Gambar 15, Gambar 16,dan Tabel 14. Displacement tiang arah X yang terjadi pada tanah lunak, sedang, dan keras memiliki nilai yang sama besar di atas kepala tiang dan displacement arah $\mathrm{X}$ untuk bagian tiang yang tertanam pada tanah lunak lebih kecil dari pada tanah sedang dan tanah keras yang dapat dilihat di Gambar 17. Displacement tiang arah Y yang terjadi pada tanah keras memiliki nilai paling kecil diikuti tanah sedang, dan tanah lunak yang dapat dilihat di Gambar 18. 
Tabel 14. Hasil analisis tiang akibat gempa lander

\begin{tabular}{ccccccc}
\hline $\begin{array}{c}\text { Jenis } \\
\text { Tanah }\end{array}$ & Phase & $\begin{array}{c}\text { Normal } \\
(\mathbf{k N})\end{array}$ & $\begin{array}{c}\text { Lintang } \\
(\mathbf{k N})\end{array}$ & $\begin{array}{c}\text { Momen } \\
(\mathbf{k N m})\end{array}$ & $\begin{array}{c}\text { Displacement X } \\
(\mathbf{m m})\end{array}$ & $\begin{array}{c}\text { Displacement } \mathbf{Y} \\
(\mathbf{m m})\end{array}$ \\
\hline \multirow{2}{*}{ Tanah Lunak } & Phase 2 & 34,221 & 34,873 & 109,673 & 20,605 & 1,331 \\
& Phase 3 & 34,794 & 99,124 & 232,042 & 49,734 & 1,110 \\
\multirow{2}{*}{ Tanah Sedang } & Phase 2 & 45,247 & 43,976 & 148,614 & 22,966 & 1,086 \\
\multirow{2}{*}{ Tanah Keras } & Phase 3 & 37,593 & 114,998 & 270,248 & 49,734 & 0,718 \\
& Phase 2 & 57,926 & 91,647 & 203,024 & 21,183 & 0,735 \\
& Phase 3 & 38,175 & 97,622 & 248,165 & 49,734 & 0,296 \\
\hline
\end{tabular}
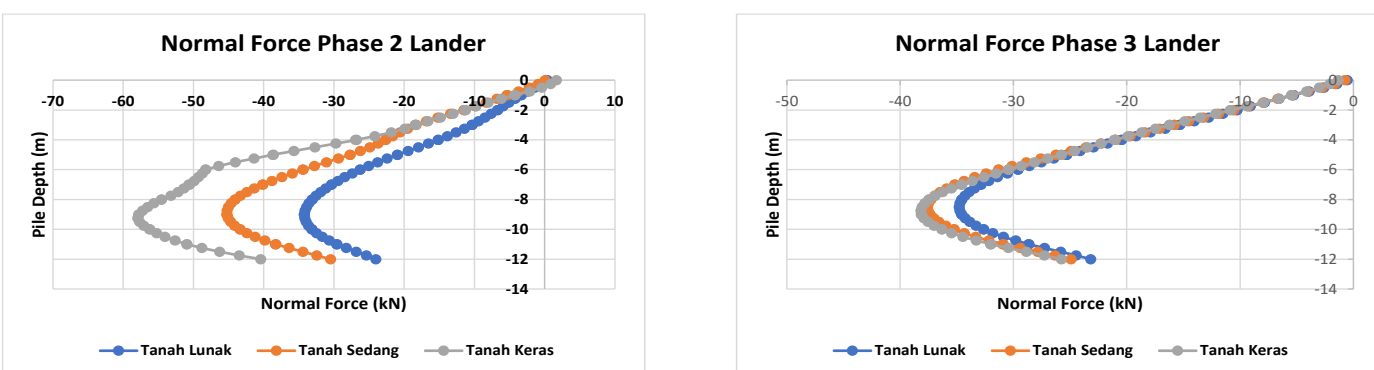

Gambar 14. Normal force tiang akibat gempa lander
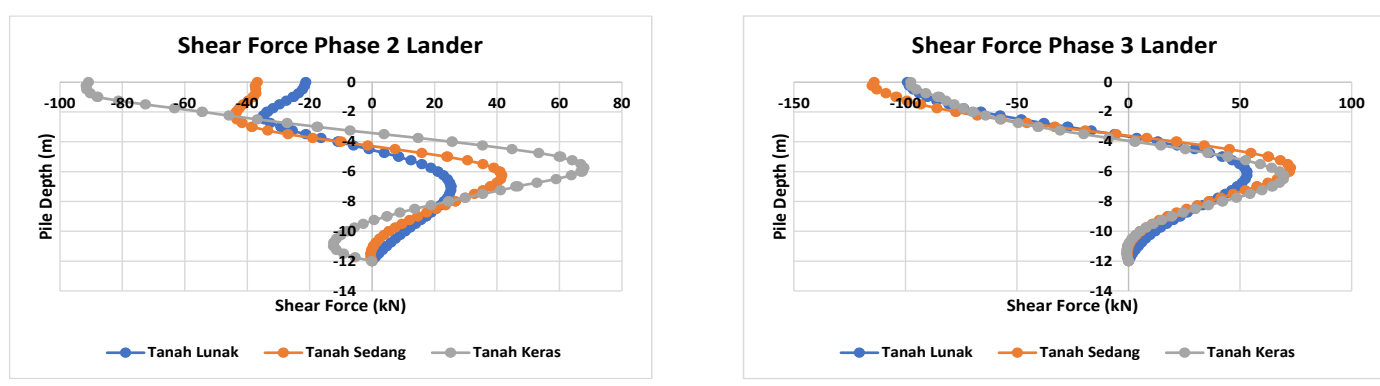

Gambar 15. Shear force tiang akibat gempa lander
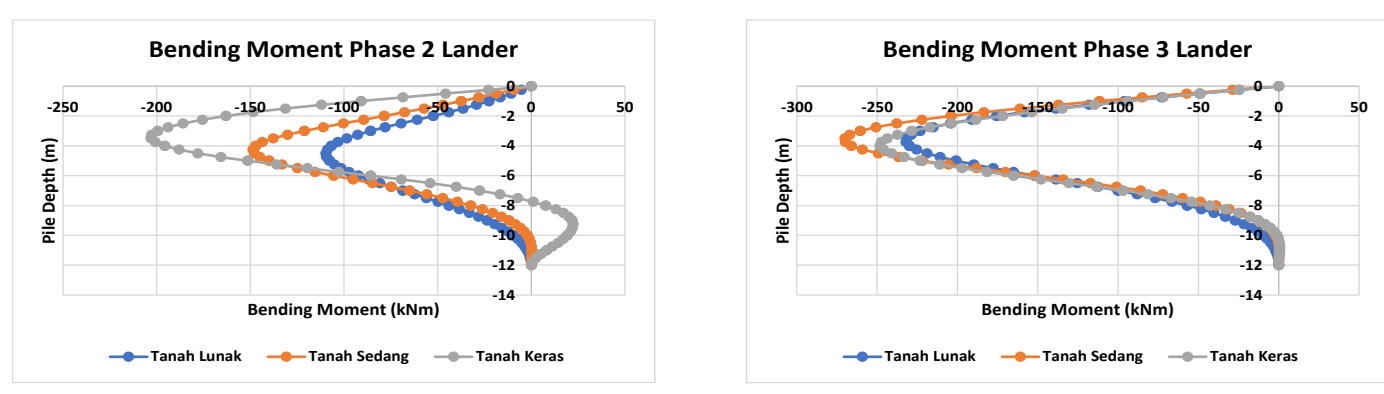

Gambar 16. Bending moment tiang akibat gempa lander
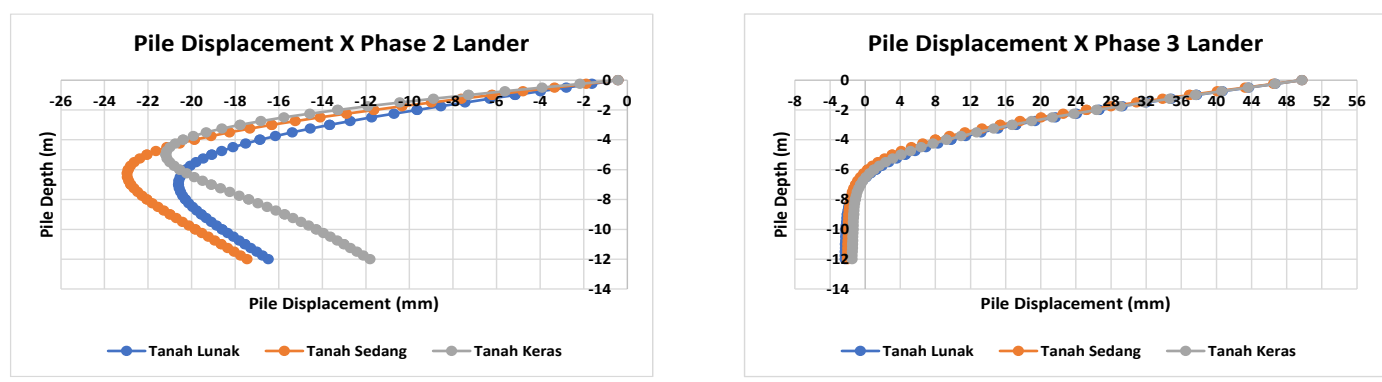

Gambar 17. Displacement tiang arah x akibat gempa lander 

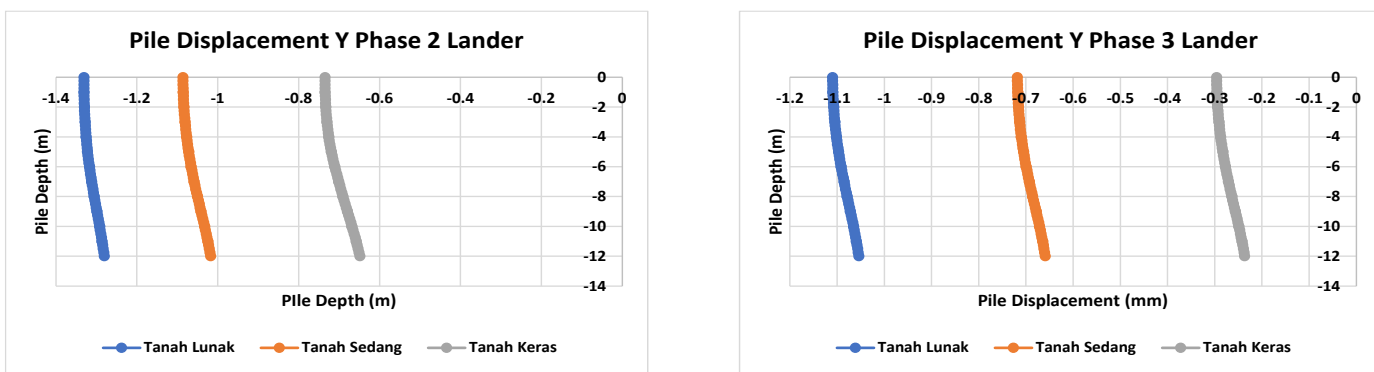

Gambar 18. Displacement tiang arah y akibat gempa lander

\section{Resume hasil analisis tiang}

Resume hasil analisis maksimum tiang dari 11 riwayat waktu gempa sesar dapat dilihat di Tabel 15 dan Tabel 16. Resume hasil analisis tiang dapat dilihat juga di Gambar 19, Gambar 20, Gambar 21, Gambar 22, Gambar 23.

Tabel 15. Resume gaya dalam maksimum tiang

\begin{tabular}{cccccccccc}
\hline \multirow{2}{*}{ Gempa } & $\begin{array}{c}\text { Tanah } \\
\text { Lunak }\end{array}$ & $\begin{array}{c}\text { Tanah } \\
\text { Sedang }\end{array}$ & $\begin{array}{c}\text { Tanah } \\
\text { Keras }\end{array}$ & $\begin{array}{c}\text { Tanah } \\
\text { Lunak }\end{array}$ & $\begin{array}{c}\text { Tanah } \\
\text { Sedang }\end{array}$ & $\begin{array}{c}\text { Tanah } \\
\text { Keras }\end{array}$ & $\begin{array}{c}\text { Tanah } \\
\text { Lunak }\end{array}$ & $\begin{array}{c}\text { Tanah } \\
\text { Sedang }\end{array}$ & $\begin{array}{c}\text { Tanah } \\
\text { Keras }\end{array}$ \\
\cline { 2 - 10 } Normal $(\mathbf{k N})$ & \multicolumn{6}{c}{ Lintang $(\mathbf{k N})$} & \multicolumn{3}{c}{ Momen $(\mathbf{k N m})$} \\
\hline Christchurch & 29,354 & 32,127 & 38,746 & 23,689 & 29,124 & 35,694 & 35,962 & 47,641 & 47,669 \\
Duzce & 43,085 & 34,675 & 61,157 & 35,012 & 43,927 & 44,397 & 50,994 & 62,962 & 75,755 \\
Imperial Valley & 45,811 & 44,984 & 57,131 & 75,456 & 91,074 & 56,544 & 155,408 & 190,789 & 149,427 \\
Kobe & 36,931 & 42,371 & 32,579 & 44,898 & 55,819 & 58,678 & 63,28 & 72,032 & 89,974 \\
Kocaeli & 37,555 & 41,108 & 44,758 & 60,692 & 73,943 & 63,755 & 108,681 & 132,229 & 127,623 \\
Lander & 34,794 & 45,247 & 57,926 & 99,124 & 114,998 & 97,622 & 232,042 & 270,248 & 248,165 \\
Lomaprieta & 18,268 & 21,112 & 29,235 & 6,504 & 9,725 & 9,698 & 11,212 & 15,209 & 18,952 \\
Northridge & 38,308 & 42,387 & 55,872 & 28,969 & 38,381 & 23,61 & 38,426 & 55,131 & 44,318 \\
Tabas & 52,446 & 43,202 & 81,032 & 87,397 & 99,101 & 66,7 & 185,409 & 195,249 & 186,162 \\
Parkfield & 11,14 & 11,382 & 11,896 & 12,786 & 10,616 & 17,069 & 12,052 & 10,115 & 17,171 \\
Chi-Chi & 45,873 & 41,755 & 52,466 & 10,078 & 7,222 & 26,425 & 19,701 & 6,409 & 37,552 \\
\hline
\end{tabular}

Tabel 16. Resume displacement maksimum tiang arah $\mathrm{x}$ dan $\mathrm{y}$

\begin{tabular}{ccccccc}
\hline & $\begin{array}{c}\text { Tanah } \\
\text { Lunak }\end{array}$ & $\begin{array}{c}\text { Tanah } \\
\text { Sedang }\end{array}$ & $\begin{array}{c}\text { Tanah } \\
\text { Keras }\end{array}$ & $\begin{array}{c}\text { Tanah } \\
\text { Lunak }\end{array}$ & $\begin{array}{c}\text { Tanah } \\
\text { Sedang }\end{array}$ & $\begin{array}{c}\text { Tanah } \\
\text { Keras }\end{array}$ \\
\cline { 2 - 7 } & \multicolumn{2}{c}{ Displacement arah x } & $(\mathbf{m m})$ & \multicolumn{2}{c}{ Displacement arah y (mm) } \\
\hline Christchurch & 4,62 & 5,594 & 4,974 & 1,336 & 0,747 & 0,361 \\
Duzce & 6,141 & 6,141 & 6,141 & 1,443 & 0,779 & 0,421 \\
Imperial Valley & 32,878 & 32,878 & 32,878 & 1,677 & 0,783 & 0,677 \\
Kobe & 10,77 & 10,77 & 10,77 & 1,608 & 0,877 & 0,227 \\
Kocaeli & 17,867 & 17,867 & 17,867 & 1,719 & 0,921 & 0,223 \\
Lander & 49,734 & 49,734 & 49,734 & 1,331 & 1,086 & 0,735 \\
Lomaprieta & 1,792 & 1,792 & 1,793 & 0,864 & 0,556 & 0,328 \\
Northridge & 7,159 & 7,159 & 7,159 & 1,748 & 0,821 & 0,449 \\
Tabas & 46,762 & 46,762 & 46,762 & 2,516 & 1,403 & 1,042 \\
Parkfield & 2,155 & 2,155 & 2,155 & 0,635 & 0,402 & 0,171 \\
Chi-Chi & 8,339 & 8,382 & 8,339 & 2,336 & 1,31 & 0,463 \\
\hline
\end{tabular}
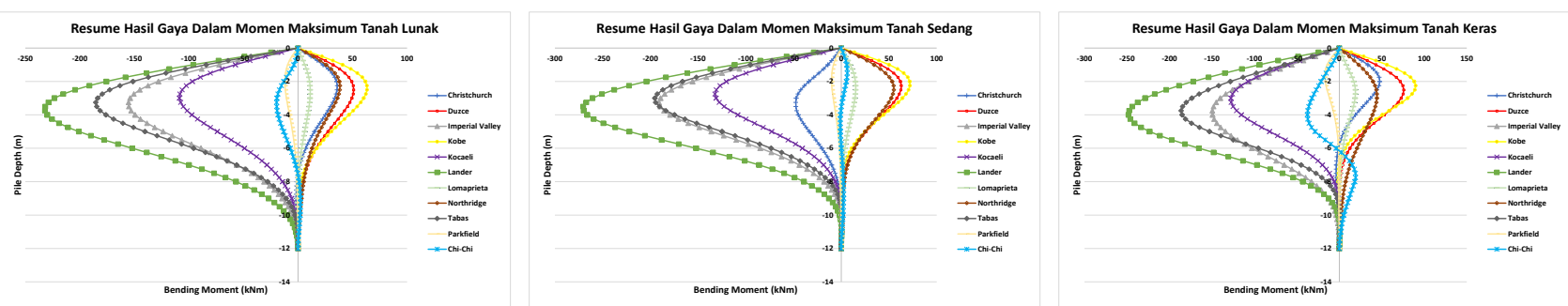

Gambar 19. Resume hasil gaya dalam momen tiang 

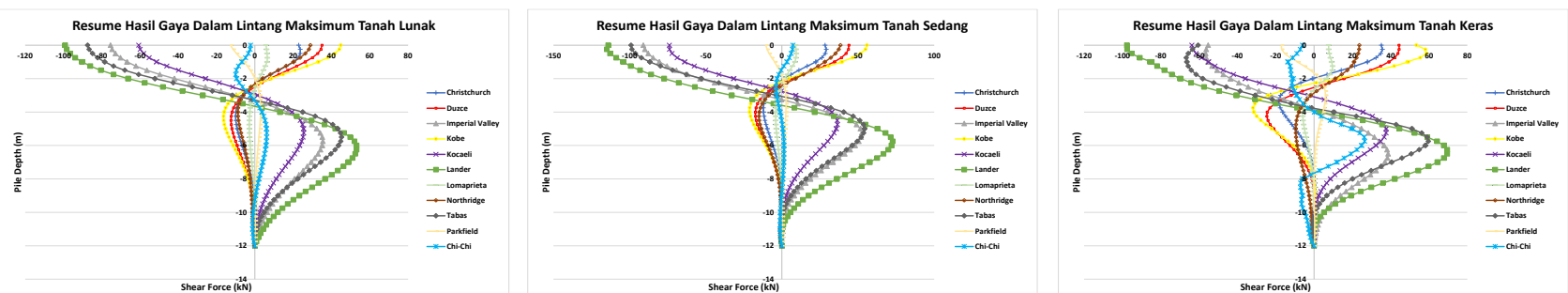

Gambar 20. Resume hasil gaya dalam lintang tiang
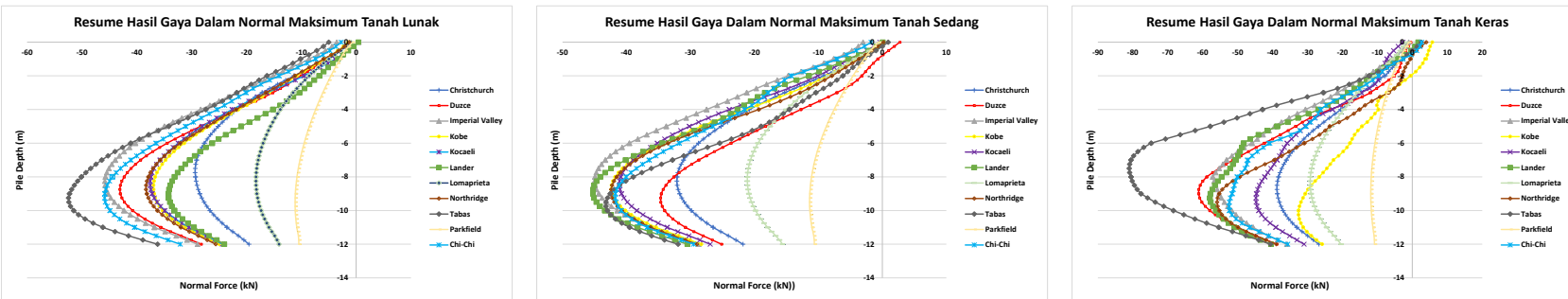

Gambar 21. Resume hasil gaya dalam normal tiang
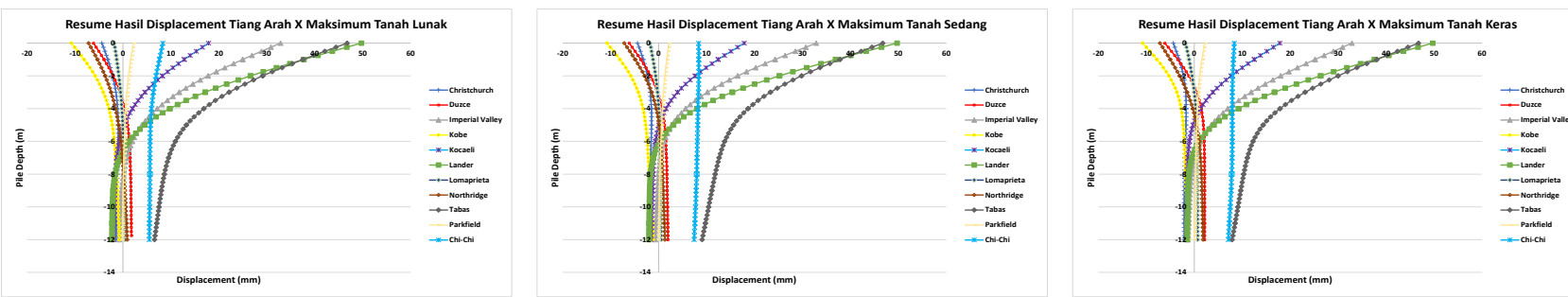

Gambar 22. Resume displacement tiang arah X
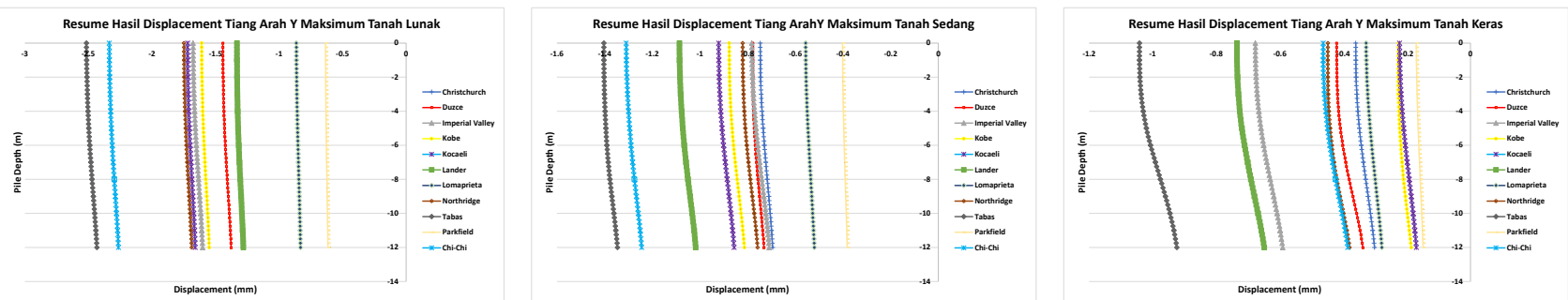

Gambar 23. Resume displacement tiang arah Y

\section{KESIMPULAN DAN SARAN}

\section{Kesimpulan}

Berdasarkan hasil analisis, maka kesimpulan yang didapat yaitu:

1. Berdasarkan hasil analisis tiang dengan menggunakan program berbasis geoteknik dapat disimpulkan bahwa tiang di tanah keras mengalami gaya dalam normal tekan paling besar dibandingkan tanah lunak dan tanah sedang.

2. Berdasarkan hasil analisis tiang dengan menggunakan program berbasis geoteknik dapat disimpulkan bahwa tiang di tanah keras mengalami displacement arah Y ke bawah paling kecil dari pada tanah sedang dan tanah lunak.

3. Berdasarkan hasil analisis tiang dengan menggunakan program berbasis geoteknik dapat disimpulkan bahwa tiang di tanah lunak, sedang, dan keras mengalami displacement arah X yang sama besar, sedangkan displacement di bagian tiang yang tertanam pada tanah lunak lebih kecil dari pada tanah sedang dan tanah keras. Displacement yang terjadi di atas tiang sama dikarenakan tahanan tanah di $0 \mathrm{~m}$ tidak diperhitungkan oleh program sehingga hasil di semua tanah sama dan beban juga diletakkan di atas tiang sehingga kepala tiang langsung menerima beban gempa. 
4. Berdasarkan hasil analisis tiang dengan menggunakan program berbasis geoteknik dapat disimpulkan bahwa tiang akibat gempa Lander mengalami dampak paling besar dari semua riwayat waktu gempa sesar, hal ini dapat dilihat dari gaya dalam momen yang terjadi pada tiang. Lander memiliki frekuensi terbesar yang dapat dilihat di fourier spectrum sehingga getaran yang terjadi pada satuan waktu semakin banyak maka dari itu fondasi mengalami suatu gerakan bolak-balik yang semakin banyak pada saat waktu interval gempa.

5. Berdasarkan hasil analisis tiang dengan menggunakan program berbasis geoteknik dapat disimpulkan bahwa semakin lama waktu interval gempa tidak membuat gaya dalam yang terjadi pada tiang akan semakin besar. Hal ini karena program menyimpan hasil berdasarkan dimana akselerasi terbesar. Pemakaian waktu interval gempa juga mempengaruhi hasil dari output program, hal ini dapat dilihat dari tabel perbandingan antara phase ke 2 dan phase ke 3. Perbedaan hasil ini kemungkinan dikarenakan input signal yang dimasukkan pada program tidak sesuai dengan yang diolah oleh program sehingga menambahkan phase ke 3 untuk melihat dimana step terakhir saat akselerasi terbesar.

6. Berdasarkan hasil analisis tiang dengan menggunakan program berbasis geoteknik dapat disimpulkan bahwa magnitudo yang semakin besar tidak mempengaruhi hasil dari gaya dalam yang terjadi. Hal ini dapat terjadi karena dalam suatu lokasi gempa memiliki stasiun yang berbeda sehingga beban gempa dalam bentuk akselerasi yang didapat juga berbeda-beda.

\section{Saran}

1. Perlu dilakukan analisis tiang dengan tipe dan dimensi yang berbeda seperti tipe tiang bored pile dan spun pile untuk membandingkan pengaruhnya.

2. Pada penelitian ini menggunakan 1 lapisan tanah homogen sehingga perlu dilakukan penggunaan lapisan tanah yang berbeda yang sesuai dengan kondisi nyata lapangan.

3. Pada penelitian ini hanya menggunakan gempa dengan 1 komponen horizontal sehingga untuk mendapatkan hasil lebih akurat dengan kondisi nyata diharapkan pemodelan gempa dengan menggunakan program berbasis geoteknik 3 dimensi sehingga bisa memasukkan beban 2 komponen horizontal dan 1 komponen vertikal.

4. Pada penelitian ini hanya menggunakan data 1 stasiun di lokasi gempa saja sehingga tidak mendapatkan hasil yang maksimum lokasi tersebut maka dari itu apabila ingin melakukan analisis tiang dengan riwayat waktu diharapkan menggunakan percepatan getaran tanah maksimum atau Peak Ground Accelerattion (PGA) untuk melihat efek paling parah yang bisa terjadi di lokasi tersebut.

5. Pada penelitian ini menggunakan automatic time step determination maka dari itu perlu digunakan manual time step determination untuk melihat hasil yang lebih akurat dari pengolahan input signal gempa.

\section{DAFTAR PUSTAKA}

Badan Standardisasi Nasional. Tata Cara Perencanaan Ketahanan Gempa Untuk Struktur Bangunan Gedung dan Non Gedung SNI 1726: 2019. Jakarta: Badan Standardisasi Nasional, 2019.

Broms, Bengt B. "Lateral resistance of piles in cohesionless soils." Journal of the Soil Mechanics and Foundations Division 90.3 (1964): 123-156.

Castelli, Francesco, dan Michele Maugeri. "Simplified approach for the seismic response of a pile foundation." Journal of Geotechnical and Geoenvironmental Engineering 135.10 (2009): 1440-1451.

Cho, Morris, Hendy Wijaya, dan Amelia Yuwono. "Analisis Kapasitas Lateral Pada Fondasi Tiang Tunggal Dan Tiang Kelompok Pada Tanah Pasir.” JMTS: Jurnal Mitra Teknik Sipil 3.4 (2020): 1105-1112.

Darendeli, M. B., dan K. H. Stokoe. "Development of a new family of normalized modulus reduction and material damping curves." Geotechnical Engineering Report (2001).

Decourt, L. "Prediction of load settlement relationships for foundations on the basis of the SPT-T." Ciclo de Conferencias Inter. “Leonardo Zeevaert”, UNAM, Mexico (1995): 85-104.

Hashash, Youssef MA, dan Duhee Park. "Viscous damping formulation and high frequency motion propagation in nonlinear site response analysis.” Soil Dynamics and Earthquake Engineering 22.7 (2002): 611-624.

Imai, Tsuneo. "Correlation of N value with S-wave velocity and shear modulus." (1982).

Isenhower, W. M., S. Wang, dan L. G. Vasquez. "Technical Manual for LPILE 2018, A Program for the analysis of Deep Foundations Under Lateral Loading." (2018).

Kaharuddin, M. S., Ronald Hutagalung, dan N. Nurhamdan. "Perkembangan tektonik dan implikasinya terhadap potensi gempa dan tsunami di kawasan Pulau Sulawesi." Proceeding The th HAGI and 40th IAGI Annual Convention and Exhibition (2011).

Lu, Yuan, dan Marios Panagiotou. "Characterization and representation of near-fault ground motions using cumulative pulse extraction with wavelet analysis." Bulletin of the Seismological Society of America 104.1 (2014): 410-426.

Matlock, Hudson. "Correlations for design of laterally loaded piles in soft clay." Proceedings of the Annual Offshore Technology Conference (1970): 77-94. 
Pakpahan, Suliyanti, Drajat Ngadmanto, dan Masturyono. "Analisis Kegempaan di Zona Sesar Palu Koro, Sulawesi Tengah." Lingkungan dan bencana geologi (2015): 253-264.

Reese, Lymon C., dan Robert C. Welch. "Lateral Loading of Deep Foundations in Stiff Clay." Journal of the Geotechnical Engineering Division 101.7 (1975): 633-649.

Van der Kwaak, Ben. "Modelling of dynamic pile behavior during an earthquake using PLAXIS 2D: Embedded beam (row)." Dissertation Delft University of Technology. 2015.

Vucetic, Mladen, dan Ricardo Dobry. "Effect of soil plasticity on cyclic response." Journal of geotechnical engineering 117.1 (1991): 89-107. 
